\title{
Environmental Impact of The Mechanical Coal Processing Plant
}

\author{
Witold BIALY ${ }^{1^{*}}$, Wes GREBSKI ${ }^{2}$, Greg GALECKI ${ }^{3}$ and Wojciech KANIAK ${ }^{4}$
}

Authors' affiliations and addresses:

${ }^{1}$ Silesian University of Technology, Faculty of Management and Organization, Department of Production Engineering, ul. Roosevelta 26, 41800 Zabrze, Poland

e-mail: wbialy@polsl.pl

${ }^{2}$ The Pennsylvania State University, 76 University Drive, Hazleton, PA 18202, USA e-mail:wxg3@psu.edu

${ }^{3}$ Missouri University of Science and Technology, Rolla, MO 65409, USA e-mail: ggalecki@mst.edu

${ }^{4}$ Rexroth Bosch Group Canada, Canada

\section{*Correspondence:}

Witold Bialy, Silesian University of

Technology, Faculty of Management and Organization, Department of Production

Engineering, ul. Roosevelta 26, 41-800 Zabrze, Poland

e-mail: wbialy@polsl.pl

How to cite this article:

Bialy, W., Grebski, W., Galecki, G. and Kaniak, W. (2020). Environmental Impact of The Mechanical Coal Processing Plant. Acta Montanistica Slovaca, Volume 25 (2), 139-149

DOI:

https://doi.org/10.46544/AMS.v25i2.1

\begin{abstract}
The enrichment of hard coal is one of the stages of mineral resources management. It is aimed at adapting its quality parameters to different recipients' requirements, considered as a stage of mineral resources management. This process is treated as a stage of clean coal technologies or as a process of improving the economics of mining plants, which takes place in the Mechanical Coal Processing Plant (ZMPW). Adaptation of the quality of commercial coal products to the needs of specific recipients consists of removing useless components of the excavated material. In this publication, factors having a negative impact on the environment as a result of the refining process of useful minerals carried out at the Mechanical Coal Processing Plant were analysed.

All departments and workstations in the Mechanical Coal Processing Plant (ZMPW) were analysed. The measurement results and proposals of solutions which have an impact on reducing the nuisance of working conditions on people working in these places were presented. The analysis results show that noise is an important factor influencing work comfort. The actions taken by the Plant will allow eliminating the negative impact of equipment emitting excessive noise on the environment.

The process related to the processing and adaptation of coal to market requirements was also analysed. This analysis of the production process allowed to determine the impact that this process has or may have on the natural environment. The presented results were obtained from one of the Hard Coal Mines of the Polish Mining Group S.A.
\end{abstract}

\section{Keywords}

hard coal, enrichment, Mechanical Coal Processing Plant, noise, standards, analysis 


\section{Introduction}

Coal, which is extracted from deposits, is mostly unsuitable for direct use. This is due to the high content of impurities in the form of various types of admixtures, excesses, which reduce its energy value. The extracted mineral in its volume constitutes only a part of coal; thus, it cannot be used in this form. Therefore (in order to be used), it is necessary to apply an appropriate process to obtain a commercial product of appropriate quality required by the recipient (customer) (Bolewski, 1991; Bolewski \& Gruszczyk, 1980; Blaschke, 2009; Nycz, 2000; Baic \& Blaschke, 2017). The final product is thermal or coking coal. The main parameters of thermal coal are: the grain size, calorific value, ash content, etc. In the case of coking coal, this parameter is sinterability (Bielewicz et al., 1993).

Depending on the needs and measures applied, a distinction is made between the following types of processing (Bielewicz et al., 1993):

- mechanical - in which the processing of mineral is carried out by mechanical means through:

o coal classification, in which the raw material's grains are divided into appropriate groups with specific grain sizes or desired density,

o enrichment of the excavated material, which involves the removal of unusable grains from the extracted mineral to increase the proportion of useful mineral,

- chemical - consisting in changing the chemical and mineral structure of a useful mineral.

Each Hard Coal Mine (Mining Plant) has a separate plant in which the processing of mineral into a suitable product is carried out using specialised technological processes.

The results of these processes are:

- concentrate, i.e. a raw material composed of grains of a useful mineral,

- $\quad$ an intermediate product, i.e. a raw material consisting of grains of waste rock grown together with grains of a useful mineral,

- $\quad$ waste, i.e. waste rock grains.

The plant where processes are carried out to remove impurities, admixtures and excesses in order to increase the share of coal in the unit of volume (or weight of the extracted mineral) is the Mechanical Coal Processing Plant (ZMPW) (Bielewicz et al., 1993).

The basic functions of ZPMW include:

- coal classification - screening,

- hydraulic and aerodynamic classification,

- grinding coal,

- gravity separation,

- flotation.

The extracted mineral is a mixture of grains of different sizes; thus, it cannot be used directly in this form. Therefore, it is fed to the appropriate equipment to divide the material by grain size.

A distinction is made between the following classification:

- mechanical - carried out on sieves,

- hydraulic - carried out in a water centre,

- $\quad$ air (aerodynamic) - carried out in a gas (air) centre.

In a joint project, conducted by consortium members: GIG and KOMAG, a review of the processing technology was carried out. The technology analysis showed that these technologies, and consequently machine systems for hard coal processing, are adapted to the characteristics of enriched coal, mainly type and degree of its contamination, and to quality requirements of both domestic and foreign recipients. In general, higher types of hard coal are currently enriched to a wider extent, using more modern machinery (https://www.wnp.pl, 2020).

\section{Pro-Environmental Activities}

Growing environmental awareness of the population causes that enterprises which do not respect the environment face problems in achieving their goals. Lack of activities (or limited activities) to improve the environment creates barriers to economic development. The problem of environmental protection has been partially regulated by introducing barriers in the form of legal regulations (standards). Most often, these regulations refer to the requirements for products. Pro-ecological improvement (rationalisation) of products results in such activities where the improvement process takes place in a manner conducive to maintaining the environmental balance (Adamczyk, 2004; Góralczyk, 2011). Pro-ecological activities in the production process and use of products must take place at each stage of the enterprises' operations. 
Sectors and branches of the economy are connected by a network of mutual dependencies expressed in the exchange of materials and energy, not only within one country or continent. Therefore, changes occurring in one sector of the economy can (and will) affect changes in another sector and even a region or a country. For this reason, the principle of sustainable development is used as a leading concept in all environmental activities (Kołodziej \& Maruszewska, 2015; Hąbek et al., 2019).

The essence of sustainable development principle is to carry out activities in particular sectors of the economy and social life in such a way that they will protect the resources of the natural environment while using them in a sustainable way now and in the future, thus creating the possibility of simultaneous functioning of economic and natural processes (Górzyński, 2004; Scherz et al., 2019). In particular, it concerns the natural resources mining industry.

Introduction of the principle of sustainable development in the mining industry imposes the following obligation (among others):

- the use of non-renewable natural resources must not be at the expense of future generations,

- decreasing natural resources force changes in the material flow from the moment of extraction, through processing, consumption and use (the so-called raw material life cycle) in such a way that their reuse becomes more common.

Introduction to the market of an increasing number of new products, as well as development and implementation of modern technologies, is related to the acquisition of large quantities of useful minerals (natural resources). It is connected with an increase in the environmental load and impact related to production, exploitation and management of products in their final phase (Klouda et al., 2018; Dyczkowska et al., 2020). Therefore, in addition to ecological factors, the environmental impact assessment also takes into account economic and social factors (Kołodziej et al., 2015; Maruszewska 2015; Maruszewska et al., 2020; Černecký et al., 2015). Such an activity is called eco-balance.

A comparative analysis of the environmental impact of at least two objects, such as products and their groups, processes or their elements, systems and algorithms of operation and combinations of these factors, carried out to the extent possible, is defined as eco-balance (Nowak, 2001; Podsiadłowska \& Foltynowicz, 2002; Górzyński, 2004; Adamczyk, 2004; Przybyłowski, 2005). An eco-balance is the ecological material and energy balance of a product, process, company or region (Fig. 1).

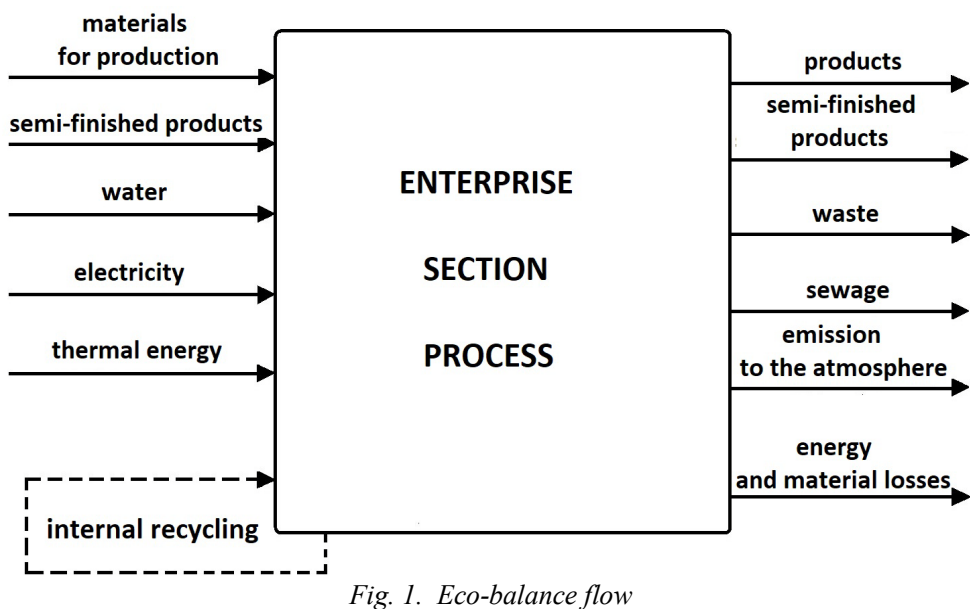

The eco-balance enables the assessment of economic processes that function in the environment both in relation to existing production systems and planned investments.

The dynamic development of new manufacturing processes and products in relation to the deteriorating natural environment conditions forces the necessity to apply comprehensive methods of environmental impact assessment.

\section{Methodology of Research}

The production process of hard coal (thermal coal, coking coal) requires a number of operations which form a logical technological sequence (Fig. 2). The extracted useful mineral (hard coal) is transported from the mining department by means of conveyors (scraper, belt conveyors) to the shaft tanks. Next, the mineral is transported to the surface, where it is refined (enriched) to obtain the final product, i.e. thermal (coking) coal. Such a process takes place at the Mechanical Coal Processing Plant (ZMPW). 
This process is very similar to different mines (Mining Plants) and is widely known and used in the mining environment (Blaschke, 2009).

The excavated mineral is initially classified on screens in two classes: $0-200 \mathrm{~mm}$ and over $200 \mathrm{~mm}$. The $+200 \mathrm{~mm}$ class is directed to the conveyor belt to remove impurities (wood, scrap, etc.). Next, the mineral is directed to the crushers. As a result of these processes, the raw material is obtained, which is directed to tanks. This tank (the so-called retention tank) is used to store the excavated material (coal), where it is then directed to the primary classification screens.

The excavated material (mineral) in the $0-200 \mathrm{~mm}$ class is directed to the screens (usually vibrating) for initial classification. Here it is divided into two classes, i.e. 0-20 mm class and 20-200 mm class.

Grain class $20-200 \mathrm{~mm}$ is enriched in suspension separator chambers. The material of $0-20 \mathrm{~mm}$ size is transported to jig (washer).

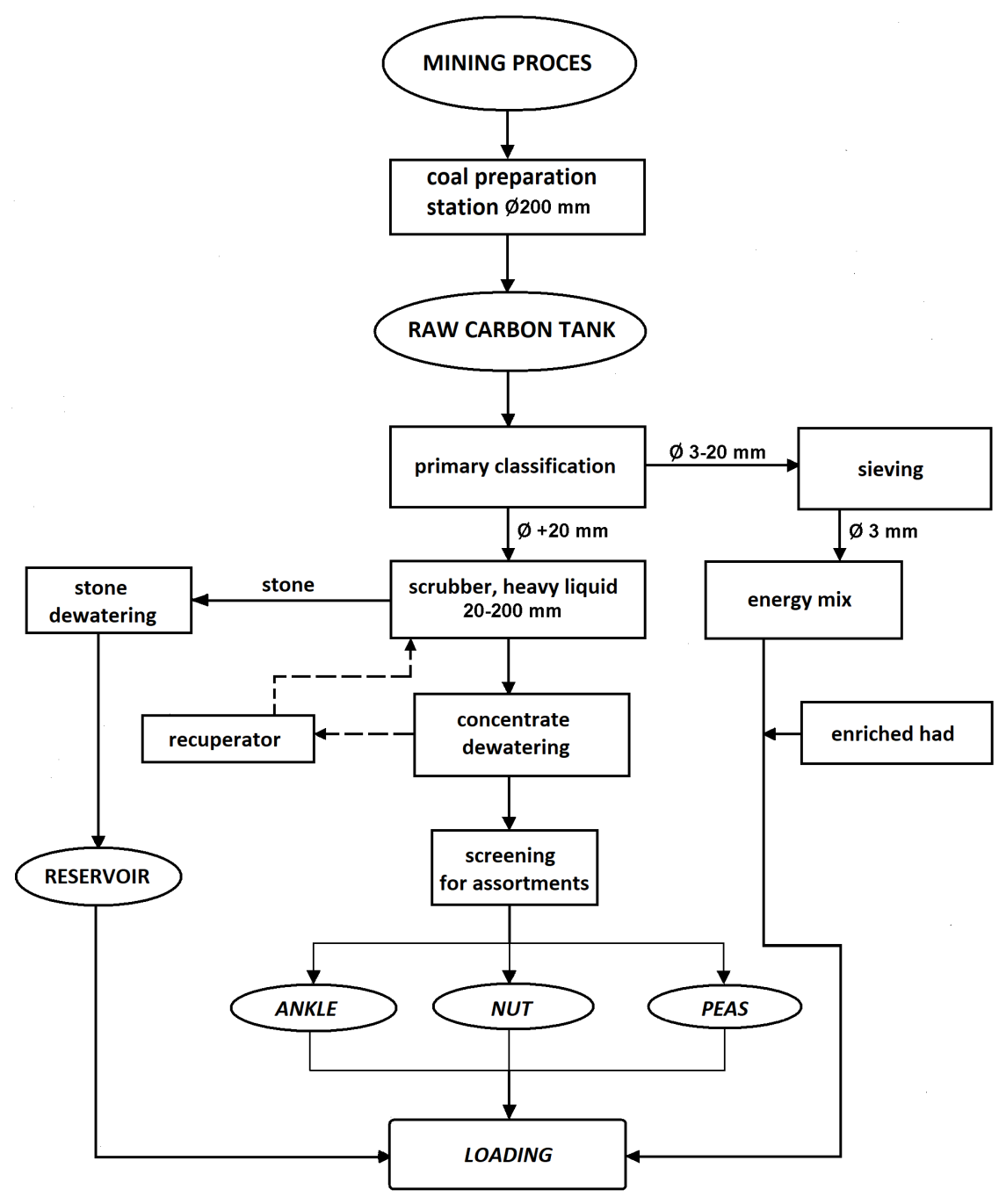

Fig. 2. Technological diagram of coal production

Enrichment in a heavy liquid is carried out on separator chambers from which coal goes to drainage screens, cooperating with a recuperator (magnetic recuperator). After enrichment in heavy liquid, the next stage is drainage of the concentrate (coal) and waste, i.e. scale. Enrichment in a heavy liquid causes the coal to contain a lot of moisture, which makes it impossible to sell it immediately (in the case of scale this is not an important reason).

The concentrate (coal) obtained in this way is then drained on screens in the next stage. The water recovered in this process is directed to a recuperator which has the task of recovering magnetite from the previously drained water. Magnetite recovery is $99 \%$. The essence of this process is also that a certain amount of water is recovered, which reduces costs.

After drainage, the enriched concentrate (thermal coal) is directed to screens to be divided into grain classes for sale (secondary classification). In this process, a finished product is obtained for sale. The waste is stored in tanks and then disposed of. 
An important element of this process is a closed water cycle. This circuit includes: heavy liquid scrubber, drainage on sieves, recuperator, water tank and magnetite. This closed-circuit allows to minimise water consumption and to recover the component necessary in this process (magnetite).

In most cases, ZMPW facilities operate for 16 hours a day - the engine power of individual devices during operation is used in about $50 \%$. The installed power is used only in case of a start-up or in case of unfavourable operating conditions.

Strict EU legislation on environmental requirements forces mines (Mining Plants) to carry out tasks that reduce the negative impact on the environment.

\section{Results of Research - Mine Pro-Ecological Activities KWK's surface protection activities}

KWK's mining operations have a significant impact on the natural environment. In order to protect the surface against the unfavourable effects of mining exploitation, the mine takes actions to protect the surface on an ongoing basis and conducts rehabilitation operations covering the areas of municipalities where the mining area is located (Białecka \& Biały, 2014; Biały \& Mroczkowska, 2015).

In order to minimise the adverse effects of mining exploitation on the surface, the mine's activity consists of the following:

- $\quad$ underground exploitation includes surface protection and proper management of the deposit,

- coordination of mining operations in order to minimise the adverse summation of surface impacts,

- cavings are sealed on an ongoing basis with a mixture of smoke-box dust and flotation waste, which reduces the reduction of the land surface,

- the mine bears the costs of protection against the impact of mining operations on the facilities under construction.

\section{Waste management activities of KWK}

Post-production waste management at KWK is an important element supporting activities related to environmental protection. This waste, generated mainly in the mining and processing operations, is recorded and minimised.

Table 1 shows the types and quantities of waste generated in these processes in one of the hard coal mines. It follows (Table 1) that most of the waste is generated in the process of mineral cleaning and washing (flotation).

Table 1. Waste generated in KWK

\begin{tabular}{|c|c|c|c|}
\hline Lp & Code & Waste type & Quantity Mg \\
\hline 1. & 010102 & Waste from the mining of minerals other than metal ores & 22137 \\
\hline 2. & 010412 & Wastes from mineral washing and cleaning other than those mentioned in 010407 and 010411 & 690656 \\
\hline 3. & 010481 & Wastes from the flotation enrichment of coal other than those mentioned in 010480 & 40300 \\
\hline 4. & 070213 & Plastic waste & 0.40 \\
\hline 5. & 150102 & Plastic packaging & 0.20 \\
\hline 6. & 160214 & Discarded equipment other than those mentioned in 160209 and 160213 & 42.30 \\
\hline 7. & 160509 & Spent chemicals other than those mentioned in 160506 and 160507 or 160508 & 1.40 \\
\hline 8. & 170201 & Wood & 24.50 \\
\hline 9. & 170405 & Iron \& Steel & 1160.50 \\
\hline 10. & 170407 & Mixtures of non-ferrous metals & 2.90 \\
\hline 11. & 170411 & Cables other than those mentioned in 170410 & 69.80 \\
\hline 12. & 191306 & Sludges from groundwater treatment other than those mentioned in 191305 & 3430.00 \\
\hline 13. & 060201 & Calcium hydroxide (ostarite) & 0.73 \\
\hline 14. & $060405^{*}$ & Waste containing other heavy metals (sludge from electrolyte filtration) & 0.002 \\
\hline 15. & $130110 *$ & Mineral hydraulic oils free of halogenated organic substances & 7.353 \\
\hline 16. & $130208^{*}$ & Other engine, gear and lubricating oils & 5.23 \\
\hline 17. & $160213 *$ & $\begin{array}{l}\text { Discarded equipment containing hazardous components other than those mentioned in } 160209 \\
\text { to } 160212\end{array}$ & 0.224 \\
\hline 18. & $160215^{*}$ & Hazardous components removed from used equipment (mercury) & 0.022 \\
\hline 19. & $100601^{*}$ & Lead batteries and accumulators & 2.42 \\
\hline 20. & $160602 *$ & Nickel-cadmium batteries and accumulators & 0.66 \\
\hline 21. & $160606^{*}$ & Selectively collected electrolyte from batteries and accumulators & 1.52 \\
\hline 22. & $180103 *$ & Other wastes that contain live pathogens & 0.083 \\
\hline
\end{tabular}

* - hazardous waste

The reasons for waste generation are related to the basic activity of the mine - they are unavoidable, but their reduction should be a priority of pro-ecological activities.

KWK carries out activities to recover waste generated in the mining process - some of this waste is managed by KWK, some is transferred to other (external) companies that specialise in the disposal or recovery of certain raw materials, compounds (Table 2). 
Table 2. Waste transferred to external companies

\begin{tabular}{|c|c|c|c|}
\hline Lp. & Code & Waste type & Quantity Mg \\
\hline 1. & $060201^{*}$ & Calcium hydroxide (ostarite) & 1.594 \\
\hline 2. & $060405^{*}$ & Waste containing other heavy metals & 0.005 \\
\hline 3. & $160602^{*}$ & Nickel-cadmium accumulators & 0.80 \\
\hline 4. & $160213^{*}$ & Used equipment containing hazardous components & 0.339 \\
\hline 5. & $160215^{*}$ & Hazardous components removed from used equipment (mercury) & 0.022 \\
\hline 6. & $180103^{*}$ & Other wastes that contain live pathogens & 0.083 \\
\hline 7. & 010102 & Waste from the mining of minerals other than metal ores & 690656 \\
\hline 8. & 010412 & Plastes arising from washing and cleaning of minerals & 1.08 \\
\hline 9. & 070213 & Plastic packaging & 0.51 \\
\hline 10. & 150102 & Used chemicals & 2.56 \\
\hline 11. & 160509 & Wood & 42.30 \\
\hline 12. & 160214 & Discarded equipment other than those mentioned in 160209 and 160213 & 24.50 \\
\hline 13. & 170201 & Iron \& Steel & 1160.50 \\
\hline 14. & 170405 & Cables other than those mentioned in 170410 & 2.90 \\
\hline 15. & 170407 & & 69.80 \\
\hline 16. & 170411 & & \\
\hline
\end{tabular}

Protection of ambient air

Emissions from the combustion of fuels and dust, methane (annual average) were shown in Table 3.

Table 3. Gaseous pollutants emitted

\begin{tabular}{|c|c|}
\hline Type of emission & Mg emissions \\
\hline Dusts & 7.07 \\
\hline Methane & 15479.77 \\
\hline Combustion of fuels & 65.88 \\
\hline
\end{tabular}

In order to reduce dust emissions, special devices have been installed in many places - mainly in the places where they arise.

These places include:

- transfer stations,

- dust and concentrate tanks.

\section{Protection against noise emissions}

Noise penetrating into the environment from the area of KWK operations results in exceeding the limit values both during day and night time (Engel et al., 2005; PN, 2000; PN 2005; Biały \& Żukowska, 2011). The mine carries out activities aimed at limiting the noise penetrating to the environment in order to achieve a satisfactory effect at the border of objects subject to noise protection. Therefore, the building of fan stations has been soundproofed, the exit has been suppressed, and the air inlet and outlet suppressors for cooling the fan motors have been enclosed. The concept of soundproofing the equipment emitting excess noise to the environment was developed, and a schedule of activities aimed at reducing its nuisance was defined.

The adopted schedule of investment activities will enable the elimination of the negative impact of equipment emitting excessive noise to the environment.

Water protection, water and wastewater management

The ecological effect in the area of water and sewage management at KWK has been achieved thanks to activities in which the "produced" waste is reused and does not constitute a nuisance to the environment. The activities of KWK in order to reduce the discharge of polluted groundwater into surface watercourses were presented in Table 4.

The underground water from KWK drainage is used for:

- fire prevention,

- depositing flotation waste,

- backfill,

- filling the closed circulation of a scrubber,

- production of drinking water. 
Table 4. Measures to reduce the discharge of polluted water

\begin{tabular}{|c|c|c|c|}
\hline Lp. & Task name & Task description & $\begin{array}{c}\text { Achieved } \\
\text { environmental effect }\end{array}$ \\
\hline 1 & $\begin{array}{l}\text { Placing smoke-box dust in underground } \\
\text { excavations }\end{array}$ & $\begin{array}{l}\text { Use of saline water and reduction of salt load discharged } \\
\text { to surface water }\end{array}$ & $317.7 \mathrm{Mg}$ \\
\hline 2 & $\begin{array}{l}\text { Placing flotation tailings in underground } \\
\text { excavations }\end{array}$ & $\begin{array}{l}\text { Use of saline water and reduction of salt load discharged } \\
\text { to surface water }\end{array}$ & $392 \mathrm{Mg}$ \\
\hline 3 & $\begin{array}{l}\text { Use of underground water in the fire } \\
\text { protection and sprinkler system }\end{array}$ & $\begin{array}{l}\text { Use of saline water and reduction of salt load discharged } \\
\text { to surface water }\end{array}$ & $2640 \mathrm{Mg}$ \\
\hline 4 & $\begin{array}{l}\text { Use of underground water in a } \\
\text { mechanical processing plant }\end{array}$ & $\begin{array}{l}\text { Use of saline water and reduction of salt load discharged } \\
\text { to surface water }\end{array}$ & $3315.6 \mathrm{Mg}$ \\
\hline 5 & $\begin{array}{l}\text { Selective abstraction and management } \\
\text { of drinking water }\end{array}$ & Limitation of underground water discharge & $\begin{array}{l}643.1 \text { thousand } \mathrm{m}^{3} \\
\text { Salt load limitation } \\
\text { quantity of } 770 \mathrm{Mg}\end{array}$ \\
\hline 6 & $\begin{array}{l}\text { Suspension precipitation in water } \\
\text { galleries - suspension storage in } \\
\text { underground workings }\end{array}$ & Limitation of suspended solids discharge & $3430 \mathrm{Mg}$ \\
\hline 7 & $\begin{array}{l}\text { Construction of threshold and dam } \\
\text { systems }\end{array}$ & Reduction of incoming slurry discharge & $498 \mathrm{Mg}$ \\
\hline 8 & Traffic elimination & $\begin{array}{l}\text { Reduction of the inflow from the eliminated traffic by } \\
\text { retaining water in the underground excavations and } \\
\text { backing up some inflows to the equilibrium level }\end{array}$ & 1624 thousand $\mathrm{m}^{3}$ \\
\hline 9 & Level elimination & $\begin{array}{l}\text { Reduction of water inflow from the decommissioned level } \\
\text { through blocking }\end{array}$ & 62.5 thousand $\mathrm{m}^{3}$ \\
\hline
\end{tabular}

\section{Environmental Impact Assessment}

Based on the adopted environmental priorities, as a result of mining activities, the significance of potential environmental impacts in the adopted categories was determined (Table 5) (Lozińska, 2006).

Table 5. Categories of environmental impacts of production processes

\begin{tabular}{|c|c|c|c|c|}
\hline \multirow[b]{2}{*}{$\begin{array}{l}\text { Impact } \\
\text { category }\end{array}$} & \multirow[b]{2}{*}{ Description } & \multicolumn{3}{|c|}{ Protection areas } \\
\hline & & Resources & $\begin{array}{l}\text { Health } \\
\text { human }\end{array}$ & $\begin{array}{c}\text { Ecosystem } \\
\text { quality }\end{array}$ \\
\hline \multicolumn{5}{|c|}{ RESOURCE DEPLETION } \\
\hline $\begin{array}{l}\text { Depletion } \\
\text { of abiotic resources }\end{array}$ & $\begin{array}{l}\text { Coal production takes place on the extracted raw material. } \\
\text { Production affects the use of non-renewable resources } \\
\text { through significant use of electricity, which is produced, } \\
\text { among others, from coal. }\end{array}$ & + & & \\
\hline \multicolumn{5}{|c|}{$\begin{array}{ll}\text { CONTAMINATION } \\
\end{array}$} \\
\hline Greenhouse effect & No impact & & $(+)$ & + \\
\hline Ozone depletion & No impact & & $(+)$ & + \\
\hline $\begin{array}{l}\text { Contamination } \\
\text { of people }\end{array}$ & $\begin{array}{l}\text { Coal production exposes workers to an environment where } \\
\text { dust content and noise emission standards are exceeded. }\end{array}$ & & + & \\
\hline $\begin{array}{l}\text { Water and soil } \\
\text { contamination }\end{array}$ & $\begin{array}{l}\text { Contamination of soil or water may be caused by muddy } \\
\text { or dirty water and residues from flotation enrichment - } \\
\text { flotation reagent and flutulant }\end{array}$ & & $(+)$ & + \\
\hline $\begin{array}{l}\text { Creation } \\
\text { of photochemical } \\
\text { oxidants }\end{array}$ & No impact & & + & + \\
\hline Acidification & No impact & & $(+)$ & + \\
\hline Eutrophication & No impact & & & + \\
\hline \multicolumn{5}{|c|}{ ECOSYSTEM AND LANDSCAPE DEGRADATION } \\
\hline Land use & ZMPW occupies a certain area of the earth's surface & & & + \\
\hline
\end{tabular}

$(+)$ - indirect impact

\section{Discussion}

By assigning revenues to the ZMPW activities, it can be concluded that the coal production processes affect humans mainly by exceeding the permissible noise level. They also have a negative impact by exceeding the permitted dust concentration and "land use". The impact of fine dust enrichment and subsequent processes (ZMPW) on the environment is also important in this process. These processes generate a huge quantity of dirty water, and flotation enrichment additionally exposes the environment to contact with flotation reagent and flocculant.

All tasks related to this production stage for environmental safety and reduction of enrichment costs are combined and form one closed water-sludge circuit, which reduces the environmental impact quite significantly. 
Negative impacts on the environment in the water-sludge cycle can only occur in emergency situations, and therefore have to be classified into two categories: water and soil contamination.

The production also has an indirect environmental impact. It can be included in the category "depletion of abiotic resources", because there is a significant demand for electricity, which is produced from non-renewable resources.

It is also important that the process of coal processing does not occur spontaneously, but is inseparably related to mining.

The environmental aspects arising from coal production and their impact on the environment were presented in Table 6.

Table 6. Environmental aspects and their impact on the environment

\begin{tabular}{|c|c|c|}
\hline Effect & Environmental aspect & Environmental impact \\
\hline \multicolumn{3}{|c|}{ ENVIRONMENT } \\
\hline \multirow{3}{*}{ Carbon transport } & Noise emissions from conveyor belts & Increasing noise emissions \\
\hline & Electricity consumption & Exhaustion of resources \\
\hline & Dust emissions to the atmosphere & Air pollution \\
\hline \multirow{4}{*}{ Screening of coal } & Noise emission from the screen & Increasing noise emissions \\
\hline & Electricity consumption & Exhaustion of resources \\
\hline & Dust emissions to the atmosphere & Air pollution \\
\hline & Waste: scrap metal, wood, plastic and other & Soil contamination, surface occupation \\
\hline \multirow{3}{*}{ Crushing of coal } & Noise emissions from the crusher & Increasing noise emissions \\
\hline & Electricity consumption & Exhaustion of resources \\
\hline & Dust emissions to the atmosphere & Air pollution \\
\hline \multicolumn{3}{|c|}{ PRIMARY CLASSIFICATION } \\
\hline \multirow{3}{*}{ Screening of coal } & Noise emission from the screen & Increasing noise emissions \\
\hline & Electricity consumption & Exhaustion of resources \\
\hline & Dust emissions to the atmosphere & Air pollution \\
\hline \multirow{3}{*}{ Carbon transport } & Noise emissions from conveyor belts & Increasing noise emissions \\
\hline & Electricity consumption & Exhaustion of resources \\
\hline & Dust emissions to the atmosphere & Air pollution \\
\hline \multicolumn{3}{|c|}{ SCREENING } \\
\hline \multirow{3}{*}{ Screening of coal } & Noise emission from the screen & Increasing noise emissions \\
\hline & Electricity consumption & Exhaustion of resources \\
\hline & Dust emissions to the atmosphere & Air pollution \\
\hline \multirow{3}{*}{ Carbon transport } & Noise emissions from conveyor belts & Increasing noise emissions \\
\hline & Electricity consumption & Exhaustion of resources \\
\hline & Dust emissions to the atmosphere & Air pollution \\
\hline \multicolumn{3}{|c|}{ FINE DUST ENRICHMENT PROCESS } \\
\hline \multirow{3}{*}{ Carbon transport } & Noise emissions from conveyor belts & Increasing noise emissions \\
\hline & Electricity consumption & Exhaustion of resources \\
\hline & Dust emissions to the atmosphere & Air pollution \\
\hline \multirow{4}{*}{$\begin{array}{c}\text { Enrichment } \\
\text { in the jigging machine }\end{array}$} & Waste formation - scale & Occupancy \\
\hline & Waste formation - muddy water & Pollution of soil, water, surface area occupation \\
\hline & Electricity consumption & Exhaustion of resources \\
\hline & Noise emissions & Increasing noise emissions \\
\hline \multicolumn{3}{|c|}{ SLUDGE DRAINAGE } \\
\hline \multirow{3}{*}{ Sludge drainage } & Noise emissions & Increasing noise emissions \\
\hline & Waste formation - muddy water & Pollution of soil, water, surface area occupation \\
\hline & Electricity consumption & Exhaustion of resources \\
\hline \multicolumn{3}{|c|}{ CENTRIFUGATION OF CARBON } \\
\hline \multirow{3}{*}{$\begin{array}{c}\text { Centrifugation } \\
\text { of carbon concentrate }\end{array}$} & Noise emissions & Increasing noise emissions \\
\hline & Waste formation - dirty water & Pollution of soil, water, surface area occupation \\
\hline & Electricity consumption & Exhaustion of resources \\
\hline \multirow{3}{*}{ Carbon transport } & Noise emissions from conveyor belts & Increasing noise emissions \\
\hline & Electricity consumption & Exhaustion of resources \\
\hline & Dust emissions to the atmosphere & Air pollution \\
\hline \multirow{3}{*}{ Flotation enrichment } & FLOTATION ENRICH & NT \\
\hline & Waste generation - flotation reagent, flocculant & Pollution of soil, water, surface area occupation \\
\hline & Waste formation - dirty water & Pollution of soil, water, surface area occupation \\
\hline
\end{tabular}

The occurring environmental aspects have been divided into activities that are implemented in the main processes. As shown in Table 6, environmental impacts occur in all processes - these impacts as a result of coal production are repeated and can be appropriately grouped.

The coal processing causes (or may cause) a negative impact on the environment, which may be classified into certain areas (issues).

These areas are:

- $\quad$ increase in noise emissions,

- depletion of natural resources, 
- air pollution,

- $\quad$ soil contamination,

- water pollution,

- $\quad$ surface occupancy.

Certain processes arising in relation to coal production are influenced by us. Some of them can be reduced, while some are not influenced by us.

Processes over which we have no influence may include:

- depletion of natural resources,

- $\quad$ surface occupancy.

We have an influence on other processes to reduce the nuisance of their impact on the environment - at the same time, we must be aware that we are not able to eliminate their negative impact completely.

\section{Conclusion}

The assessment of the environmental impact of the coal production process was based on research conducted at the Mechanical Processing Plant in one of the hard coal mines. The main objective of ZMPW is to process the excavated mineral in order to ultimately provide the market with a product of appropriate quality and meet customer requirements.

The analysis of production processes at ZMPW allowed to determine the impact they have (or may have) on the natural environment.

The main processes (Fig. 2), which have a negative impact on the environment in which this process takes place are the following:

- primary classification, which is carried out on vibrating screens. The screens and auxiliary processes generate high levels of noise emission and dust concentration. These parameters exceed acceptable standards and pose a threat to both employees and the environment,

- screening (separation into grain classes 0-3 $\mathrm{mm}$ and 3-20 mm). Also in this process, noise and dust are emitted that exceeds acceptable standards, which also poses a threat to employees and the environment,

- flotation enrichment, which is used to extract the smallest grains of carbon from the water. The chemicals used in this process may have a negative impact on the environment. However, by incorporating this process into a closed water cycle, environmental risks are minimised. However, it is recommended to continuously monitor this process, which is related to the storage and supply of chemicals to this process.

The results of conducted analyses stated that there are also processes which take place in ZMPW and do not have a negative impact on the environment - they fall within the adopted standards. These processes belong to the following:

- preparation (sorting) stage of coal, where sieves and crushers are used. There is a problem of noise emission and dust generation. It was found that these parameters are included in acceptable standards,

- enrichment of the dust - this process takes place in an aqueous environment. Negative effects on the environment result from the formation of muddy water, which can be dangerous if penetrated into the environment. This also applies to the coal/scale drainage process. This problem is solved by a closed water cycle.

Conducted analysis indicates that pro-ecological activities of the mine are correct but not satisfactory manner. Those places of the production process of ZMPW have been indicated which should be given special attention.

In accordance with conducted measurements, the factor that occurs in practically each analysed place is noise.

Workers exposed to loud noise, in addition to hearing damage, are more likely to develop a variety of conditions, especially cardiovascular, respiratory and digestive tract disorders. In addition, high noise levels reduce the ability to hear, communicate and warn each other, which increases the potential risk of errors at work and thus accidents. Forced by excessive noise, the need for raising voice causes additional stress, which increases these adverse effects (Baranov et al., 2017).

Hard coal mines, in particular, the Mechanical Coal Processing Plant is characterised by a large number of workstations with noise standards exceeded. The hearing loss is irreversible as a result of excessive noise and largely limits the ability to work - this is a very serious problem of modern hard coal mines.

The harmful effects of noise on human health depend on many factors, such as: frequency of noise, the intensity of noise, duration of exposure to noise, type of noise (intermittent, continuous, impulsive), individual susceptibility to noise and the influence of other factors, such as ototoxic substances. 
For the assessment of noise harmfulness, it has been assumed (in accordance with PN-EN ISO 9612:2009) that the level of noise exposure related to the 8-hour daily working time (Lex, $8 \mathrm{~h})$ should not exceed $85 \mathrm{~dB}$, the maximum A-noise level (LAmax) should not exceed $115 \mathrm{~dB}$, and the peak C-noise level (LCpeak) should not exceed $135 \mathrm{~dB}$.

For the assessment of noise harmfulness, it has been assumed (in accordance with PN-EN ISO 9612:2009) that the level of daytime noise exposure should not exceed $65 \mathrm{~dB}$, and the level of night-time noise exposure should not exceed $45 \mathrm{~dB}$.

Knowledge of the above values allows for the determination of the level of occupational risk to workers resulting from exposure to audible noise, by means of a comparison with the limit values in force.

This analysis allows to compare environmental loads of particular processes of ZMPW and on this basis to make decisions related to modernisation of particular technological processes.

\section{References}

Adamczyk W.: (2004). Ekologia wyrobów. Polskie Wydawnictwo Ekonomiczne. Warszawa.

Baic I, \& Blaschke W.: (2017). Przeróbka węgla kamiennego w Polsce - trendy rozwoju w zakresie zwiększenia efektywności produkcji. Inżynieria Mineralna, lipiec-grudzień 2017. Journal of the Polish Mineral Engineering Society.

Baranov, M.N., Božek, P., Prajová, V., Ivanova, T.N., Novokshonov, D.N. and Korshunov, A.I. (2017). Constructing and calculating of multistage sucker rod string according to reduced stress. In Acta Montanistica Slovaca. Vol. 22, no. 2, pp. 107-115.

Białecka B, \& Biały W.: (2014). „Tereny pogórnicze - szanse, zagrożenia. Analiza przypadku” Wydawnictwo PA NOVA SA. Gliwice. ISBN 978-83-937845-4-7. p. 202

Biały W, \& Mroczkowska P.: Influence of coal waste heaps on water environment in upper silesian borderland areas - case study. $15^{\text {th }}$ SGEM GeoConference on Science and Technologies In Geology, Exploration and Mining, SGEM2015 Conference Proceedings, June 18-24, 2015, Vol. III, BUŁGARIA ISBN 978-6197105-33-9/ISSN 1314-2704. pp. 675-682.

Biały W, \& Żukowska T.: (2011). Przekroczenia hałasu na terenie zakładu przeróbki mechanicznej węgła. „Rola informatyki w naukach ekonomicznych i społecznych". Tom 1. Wydawnictwo Wyższej Szkoły Handlowej. Kielce. ISBN 978-83-89274-60-1. pp. 221-232.

Bielewicz T., Prus B., Hołysz J.: (1993). Górnictwo. Część 1. Śląskie Wydawnictwo Techniczne. Katowice.

Blaschke W.: (2009). Przeróbka Węgla Kamiennego - Wzbogacanie Grawitacyjne. Wydawnictwo Instytutu Gospodarki Mineralnymi i Energią PAN, Kraków.

Bolewski A.: (1991). W sprawie surowców mineralnych. Instytut Geologii i Surowców Mineralnych Akademii Górniczo Hutniczej w Krakowie. Wydawnictwo AGH Kraków.

Bolewski A, \& Gruszczyk H.: (1980). Geologia Gospodarcza. Skrypt AGH nr. 738. Kraków.

Černecký, J., Valentová, K., Pivarčiová, E. and Božek, P. (2015). Ionization impact on the air cleaning efficiency in the interior. Measurement Science Review [electronic source]. Vol. 15, No. 4, online, pp. 156-166

Engel Z., Sadowski J., et al.: (2005) Noise protection In Poland In European Legislation. The Committee on Acoustics of the Polish Academy of Science \& CIOP-PIB Warszawa.

Dyczkowska J, Bulhakova Y, Łukaszczyk Z, Maryniak A.: (2020) Waste Management as an Element of the Creation of a Closed Loop of Supply Chains on the Example of Mining and Extractive Industry. Management Systems in Production Engineering. Volume 28, issue 1. pp. 60-69, DOI 10.2478/mspe2020-0010

Góralczyk S., (red): (2011). Gospodarka surowcami odpadowymi z węgla kamiennego. Publikacja opracowana $\mathrm{w}$ ramach projektu: "Foresight $\mathrm{w}$ zakresie priorytetowych i innowacyjnych technologii w zakresie zagospodarowywnia odpadów pochodzących z górnictwa węgla kamiennego".

Górzyński J.: (2004). Kierunki i możliwości działania w proekologicznej racjonalizacji wyrobów przemysłowych. Gospodarka Paliwami i Energią. 11-12/2004.

Hąbek P., Biały W., Livenskaya G.: (2019) Stakeholder engagement in corporate social responsibility reporting. The case of mining companies. Acta Montanistica Slovaca. ISSN 1335-1788. Volume 24 (2019), number 1, pp. 25-34.

Klouda P, Moni V, Řehoř M, Blata J, Helebrant F.: The Evaluation of a Risk Degree for the Process of a Brown Coal Spontaneous Ignition on Dumps with Using of Modern Numeric Methods. Management Systems in Production Engineering. Volume 26, issue 2. pp. 71-75, DOI 10.2478/mspe-2018-0011

Kołodziej S, \& Maruszewska E.W., (2015). Economical Effectiveness and Social Objectives in Corporate Social Reports - a Survey Among Polish Publicly Traded Companies. $2^{\text {nd }}$ International Multidisciplinary Scientific Conference on Social Sciences and Arts SGEM2015, www.sgemsocial.org, SGEM2015 
Conference Proceedings, ISBN 978-619-7105-47-6/ISSN 2367-5659, Aug 26-Sept 01; Book 2, Vol. 2, pp. 161-167 DOI: 10.5593/SGEMSOCIAL2015/B22/S6.021

Łozińska M.: (2006). Wpływ procesów produkcyjnych Zakładu Mechanicznej Przeróbki Węgla na środowisko. Praca dyplomowa (niepublikowana) Gliwice.

Maruszewska E.W.: (2015) Applicability of activity based costing in new product development processes. Management Systems in Production Engineering 1(17). ISSN 2299-0461. pp. 35-39. DOI: 10.12914/MSPE-06-01-2015.

Maruszewska E.W, \& Strojek-Filus M.: (2020) Research and Development in the Service Sector - Vague Definition and Problematic Application. Management Systems in Production Engineering. Volume 28, issue 1. pp. 53-59, DOI 10.2478/mspe-2020-0009

Nycz R.: (2000). Aktualny stan przeróbki węgla kamiennego w Polsce. Inżynieria Mineralna, lipiec-grudzień 2000. Journal of the Polish Mineral Engineering Society.

Nowak Z. Zarządzanie środowiskiem cz. II, Wydawnictwo Politechniki Śląskiej, Gliwice 2001

Podsiadłowska A, \& Foltynowicz Z.: Ocena Cyklu Życia (LCA). Nowa metoda szacowania ekologicznych skutków działalności gospodarczej. Recykling 9/2002.

Przybyłowski P. Podstawy Zarządzania środowiskiem, Wydawnictwo Akademii Morskiej, Gdynia 2005

https://www.wnp.pl/wiadomosci/problemy-mechanicznej-przerobki-wegla-kamiennego-w-perspektywnie-roku2020,-4344.html

Scherz C, Hahn J, Ladikas M.: (2019) Technology Assessment in a Globalized World. Management Systems in Production Engineering. Volume 27, issue 3. pp. 149-152, DOI 10.1515/mspe-2019-0024

PN-EN ISO 9612:2009 Hałas. Dopuszczalne wartości hałasu w środowisku pracy. Wymagania dotyczące wykonywania pomiarów.

PN-ISO 1999:2000 Wyznaczanie ekspozycji zawodowej na hałas i szacowanie uszkodzenia słuchu wywołanego hałasem. 